\title{
The Effects of Special Sports Games Program on Physical Fitness in Adolescents with Intellectual Disability
}

\author{
Aleksandar Pejčić, Miodrag Kocić, Dragana Berić, Goran Kozomara, Marko Aleksandrović \\ Faculty of Sport and Physical Education of University of Niš, Niš, Serbia
}

\section{SUMMARY}

The aim of this research was to determine the influence of the experimental program on improving physical fitness in adolescents with intellectual disability (ID).

For the needs of a dual prospective study of the cohort, 122 adolescents aged 13 to 17 with mild ID were recruited and then divided into two groups, experimental (EG) and control (CG). The EG was subjected to a special program of sports games (SSGP) lasting 12 weeks, four times a week, with 30-minute duration of each session. CG was subjected to the program of the Ministry of Education, Science and Technological Development of the Republic of Serbia (MP), with the same duration, weekly frequency and session duration, with one session per week being the time of the selected sport. The data for 30 adolescents within EG and CG were collected for further analysis, respectively.

Physical fitness of the respondents was tested using the Eurofit fitness test battery: standing long jump (SLJ), single-arm ball pushing (SABP), sit-ups (SUP), 25-meter run (R25), seated forward bend (SFB), bench walking (BW1), and narrow bench walking (BW2).

SSGP led to statistically significant improvements in EG concerning arm's explosive strength, local muscular endurance, speed and flexibility of the hip.

The results of ANOVA and MANOVA indicated that after the implementation of SSGP, there was a statistically significant positive difference in favor of EG compared to CG.

It can be concluded that the SSGP contributed with a greater extent to the development of physical fitness than MP in adolescents with ID.

Key words: intellectual disability, physical fitness, adolescents

Corresponding author:

Aleksandar Pejčić

Email: acapejcic@yahoo.com 


\section{INTRODUCTION}

According to previous review studies, the prevalence of ID in last decades has often been quoted at $1 \%$ (1). People with diagnosed ID are people who are unable to comply with all social norms set to govern the behavior of average members of a society. There are many definitions (2) explaining how ID people behave, but one thing the researchers agree on is that such a state is organic in nature and that such skills are unchangeable (3). The character traits of these individuals are reflected in the fact that their limit or level of disability is conditioned by intelligence quotient (IQ). Therefore, to be diagnosed as having mental retardation, a person must have an IQ below 70-75, i.e. significantly below average (2). However, based on different IQ scores, these individuals are arranged into different difficulty levels (4). Typical differences that can be observed in people with ID compared to people without disabilities are: reduced cognitive and conative abilities, the occurrence of sensory disturbances, slow speech and dysarthria (difficulty speaking), reduced physical skills or motor control of movement and maintaining the balance and coordination of movement (5).

There is no limitation in movement amplitude and flexibility in people with ID whose muscle functionnality is preserved. On the other hand, due to weaker motor control, more complex movements are difficult to perform and there is no movement fluidity during performance (3). This problem is even more detectable in people with lower IQs (3). Therefore, early stimulation through physical exercise is required (6).

Moreover, people with ID have been ignored by people without disabilities from the very beginning of their lives, especially during schooling (7). This affects their discomfort in social environment and their desire to engage in some kind of physical activities (8), which results in a reduced participation in physical exercises (9). Various studies that dealt with the discovery of differences between people diagnosed with ID and people without disabilities have illustrated the aforementioned data (10). Those studies indicated great differences in physical abilities, fitness components (cardiorespiratory and cardiovascular ability) as well as in body composition which is in favor of people without disabilities $(11,12)$.

Due to the mentioned deficits and barriers, people with ID need additional support to engage in physical activities. This support should be implemented through an organized system that is adapted to the needs of people with ID and which will enable them to develop their full potential (13). Once they start preschool, people with ID can exercise through special education and sports associations. Organized physical activities through sports games at the international level are organized by the socalled "Special Olympics" (14). In such organized sports events and competitions, these people are, depending on the level of their physical abilities, classified and allowed to compete in different sports. The sports in which they compete (individual and collective) are in accordance with the rules adapted to their abilities (15). The priority of all adapted physical education experts should be finding the most suitable program for people with ID that can help them transform their physical fitness. The aim of this research was to determine the effects of the special sports games program (SSGP) on improving the physical fitness in adolescents with ID.

\section{MATERIAL AND METHODS}

\section{Examinee samples}

For the needs of a dual prospective study of the cohort, 122 adolescents aged 13 to 17 with mild ID (IQ from 50-55 to 70) were recruited and then divided into two groups, experimental (EG) and control (CG). Twelve adolescents did not get permission to participate in the study. Due to the fact that the participants were underage, a written consent form from their guardians was obligatory (Figure 1).

The EG was subjected to a special program of sports games (SSGP) lasting 12 weeks, with a frequency of 4 times a week and a duration of 30 minutes. Fiftyseven adolescents started the SSGP and the data for 30 of them were collected for further analysis (Figure 1).

CG was subjected to the regular program of the Ministry of Education, Science and Technological Development of the Republic of Serbia (MP) with the same program duration, weekly frequency and session duration, with one session per week being the time of the selected sport. MP was started by 53 adolescents, and the data for 30 were collected for further analysis (Figure 1).

Inclusion criteria for participation in the study (EG and CG, respectively) was parental consent. Study participants with competed baseline and final testing and at least $75 \%$ of all sessions attendance met the inclusion criteria for further analysis.

\section{Experimental and control program}

The EG was subjected to a special program of sports games (SSGP) lasting 12 weeks, with a frequency of four times a week and a duration of 30 minutes. 
During the classes, the examinees mastered the technical elements of football (controlling the ball, shooting at goal and passing the ball) and basketball (controlling the ball, catching the ball, passing the ball and shooting baskets). During each class, the examinees did 10 repetitions of two or more elements with previous warm-up and exercises to increase muscle tone that was activated during the class prime part. The last five minutes of the class were dedicated to muscle relaxation and preparing the body for further school activities. The SSGP was implemented in elementary and secondary school "11. Oktobar" in Leskovac. The SSGP was performed by PE teachers with over 20 years of experience with children and adolescent with ID.

CG was subjected to the regular program of the Ministry of Education, Science and Technological Development of the Republic of Serbia (MP) with the same duration, weekly frequency and session duration, with one session per week being the time of the selected sport. CG had a warm-up at the beginning of each class (strength exercises, shaping) with mandatory running. The introductory part of the lesson lasted for 15 minutes. The main part of the class was dedicated to one technical element from one of the sports (basketball, football, volleyball, handball, and athletics) or to games (folklore, dancing). The final part of the lesson, lasting from 5 to 10 minutes, was dedicated to relaxation and muscle stretching. Each Saturday, the CG would have one session of swimming for 45 minutes. The MP was conducted in elementary and secondary school "14. oktobar" in Niš (and swimming in the closed swimming pool of the sports center "Čair" in Niš). The MP was performed by PE teachers with over 20 years of experience with children and adolescent with ID.

EG and CG started their sessions during the third week in March 2017 and ended them during the second week in June 2017.

\section{Measuring instruments sample}

Eurofit fitness test battery was specially designed for people with ID to assess their physical fitness (16): standing long jump (SLJ), single-arm ball pushing (SABP), sit-ups (SUP), 25-meter run (R25), seated forward bend (SFB), wide bench walking (BW1) and narrow bench walking (BW2). For closer description of the examinees, the estimation of the anthropometric characteristics (17) was determined using the following tests: body height $(\mathrm{BH})$, body mass (BM) and body mass index (BMI), and using standardized anthropometric instruments (GPM, Swiss) (Table 1). Testing (initial and final assessments, respectively) was performed by three experienced researchers from Faculty of Sport and Physical Education of the University of Niš.

\section{Statistical data analysis}

Data processing was conducted by the SPSS statistics program (v17.0, SPSS Inc., Chicago, IL, USA).

In order to determine statistically significant differences at the univariate level of data obtained from the initial and final measurements between EG and CG, as well as within each group for each variable, a t-test for independent samples was used.

A multivariate analysis of variance (MANOVA) was used to determine differences in groups at different measurements, and the differences for each measurement instrument or variable were determined by univariate analysis of variance (ANOVA).

In order to determine the effects of a special sports games program, the neutralization of the difference at the initial measurement between the groups was performed using MANCOVA (multivariate analysis of covariance) and ANCOVA (univariate analysis of covariance).

\section{RESULTS}

In the very beginning of the study, 122 adolescents met the inclusion criteria and expressed interest to participate (Figure 1). Initially, 12 adolescents dropped out of the study due to no parental consent. In total, 110 agreed to participate in the study, completed the baseline measures and were divided into two groups regarding the place of residence - double prospective cohort study. Fifty-seven adolescents formed the EG and started SSGP. As the attendance of lessons was less than 75 $\%, 20$ children dropped out of the study. Additionally, seven children were excluded from the study due to the incompletion of the final testing and 30 adolescent within EG met the inclusion criteria for further analysis. Fiftythree adolescents formed CG and started MP. As lesson attendance was less than $75 \%, 21$ children dropped out of the study. In addition, two adolescents dropped out from the study due to the incompletion of the final testing and 30 adolescents within CG met the inclusion criteria for further analysis (Table 1).

Based on the results presented in Table 2, which describes the differences between EG and CG at the initial measurement, within the variables describing the area of physical fitness, a difference between EG and CG can be observed. The differences between the EG and CG subjects were observed in the SLJ variable in favor of EG 
where t-test statistical significance was $r=0.00$ and Cohen's d effect size was $0.49^{*}$. Also, the differences were observed in the R25 variables in favor of CG where t-test statistical significance was $r=0.00$ and Cohen's d effect size was 0.14 , as well as in the SFB variable in favor of
EG subjects, where t-test statistical significance was $\mathrm{r}=$ 0.04 and Cohen's d effect size was $0.35^{*}$. Upon completing the initial physical fitness measurement, other variables between the EG and CG subjects did not show any statistically significant differences.

122 adolescents met the inclusion criteria and expressed interest to participate

12 adolescents dropped out of the study due to no parental consent

110 adolescents agreed to participate (with parental consent), completed the baseline measures and were divided into two groups regarding the place of residence - double prospective cohort study

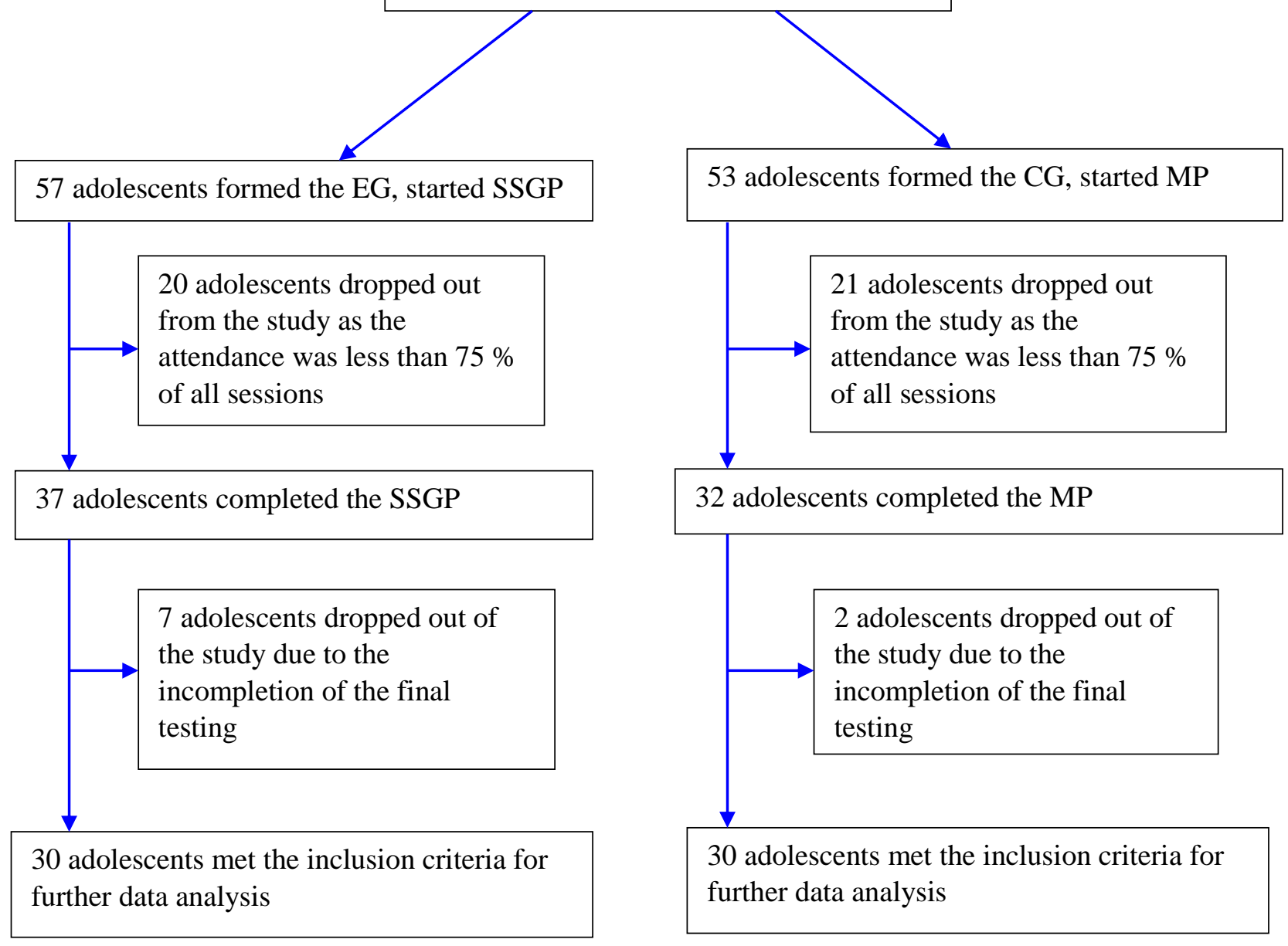

Figure 1. Design and flow of participants throughout the study 
Table 1. Chronological and anthropometric characteristics of examinees

\begin{tabular}{l|c|c|c|c}
\hline \hline Groups & \multicolumn{2}{|c|}{ EG } & \multicolumn{2}{c}{ CG } \\
\hline Variable & Mean & SD & Mean & SD \\
\hline AGE (years) & 14.99 & 1.44 & 14.96 & 1.55 \\
\hline BH (cm) & 162.90 & 9.17 & 162.87 & 12.71 \\
\hline BM (kg) & 61.65 & 14.12 & 57.56 & 17.07 \\
\hline BMI (kg/m $\left.{ }^{2}\right)$ & 18.88 & 3.90 & 20.82 & 17.38 \\
\hline \hline
\end{tabular}

EG - experimental group, CG - control group, Mean -mean value results, SD standard deviation, AGE- chronological age, BH - Body Height, BM - Body Mass, BMI - Body Mass Index.

Table 2. Initial assessment of physical fitness in EG and CG and t-tests

\begin{tabular}{|c|c|c|c|c|c|c|c|c|c|}
\hline \multirow{2}{*}{$\begin{array}{c}\text { Group } \\
\text { Variable }\end{array}$} & \multicolumn{2}{|c|}{ EG } & \multicolumn{2}{|c|}{ CG } & \multirow{2}{*}{$\begin{array}{c}\text { Mean Diff } \\
\text { EG-CG }\end{array}$} & \multirow{2}{*}{$\mathbf{t}$} & \multirow{2}{*}{ df } & \multirow{2}{*}{$\mathbf{r}$} & \multirow{2}{*}{ Cohen's c } \\
\hline & Mean & SD & Mean & SD & & & & & \\
\hline SLJ (cm) & 71.73 & 27.45 & 84.17 & 44.91 & -12.43 & -1.29 & 48.02 & 0.20 & $0.23^{*}$ \\
\hline SABP $(\mathrm{cm})$ & 6.5 & 1.58 & 3.61 & 1.55 & 2.84 & 7.03 & 58.00 & $0.00^{* *}$ & $0.49^{*}$ \\
\hline SUP (attempts) & 13.30 & 4.30 & 11.57 & 7.70 & 1.73 & 1.08 & 45.49 & 0.29 & 0.17 \\
\hline R25 (s) & 5.27 & 0.67 & 6.02 & 1.00 & -0.76 & -3.45 & 50.84 & $0.00^{* *}$ & 0.14 \\
\hline SFB (cm) & 25.00 & 8.25 & 20.20 & 9.29 & 4.80 & 2.12 & 58.00 & $0.04^{*}$ & $0.35^{*}$ \\
\hline BW1 (points) & 2.50 & 0.78 & 2.50 & 0.63 & 0.00 & 0.00 & 58.00 & 1.00 & 0.00 \\
\hline BW2 (points) & 2.30 & 0.98 & 2.17 & 0.89 & 0.07 & 0.28 & 58.00 & 0.78 & 0.01 \\
\hline
\end{tabular}

EG - experimental group, CG - control group, Mean - mean value results, SD - standard deviation of the mean, Mean Diff EG-CG - differences obtained when the arithmetic mean of the control group is subtracted from the arithmetic mean of the experimental group, $\mathrm{t}$ - calculated $\mathrm{t}$-test value, $\mathrm{df}$ - degrees of freedom, $\mathrm{r}$ - $\mathrm{t}$-test statistical significance, Cohen'sd - calculated Cohen's d effect size used to indicate the standardized difference between two means, SLJstanding long jump; SABP - single-arm ball pushing; SUP - sit-ups; R25 - 25-meter run; SFB - seated forward bend; BW1 - wide bench walking; BW2 - narrow bench walking; statistical significance of differences ${ }^{*}<0,05,{ }^{* *}<0,01$.

Table 3. Final assessment of physical fitness in EG and CG and t-tests

\begin{tabular}{|c|c|c|c|c|c|c|c|c|c|}
\hline Group & \multicolumn{2}{|c|}{ EG } & \multicolumn{2}{|c|}{$\mathrm{CG}$} & \multirow{2}{*}{$\begin{array}{c}\text { Mean Diff } \\
\text { EG-CG }\end{array}$} & \multirow{2}{*}{$\mathbf{t}$} & \multirow{2}{*}{ df } & \multirow{2}{*}{$\mathbf{r}$} & \multirow{2}{*}{ Cohen's d } \\
\hline Variable & Mean & SD & Mean & SD & & & & & \\
\hline SLJ (cm) & 77.40 & 28.10 & 82.83 & 12.79 & -5.43 & -0.57 & 49.23 & 0.57 & 0.10 \\
\hline SABP $(\mathrm{cm})$ & 6.81 & 1.66 & 3.52 & 17.50 & 3.29 & 8.06 & 58.00 & $0.00^{* *}$ & $0.56^{* *}$ \\
\hline SUP (attempts) & 16.83 & 4.76 & 10.97 & 7.44 & 5.87 & 3.64 & 49.34 & $0.00^{* *}$ & $0.57^{* *}$ \\
\hline R25 (s) & 5.24 & 0.64 & 6.09 & 1.02 & -0.86 & -3.90 & 58.00 & $0.00^{* *}$ & 0.16 \\
\hline SFB (cm) & 30.00 & 11.40 & 19.13 & 9.02 & 10.87 & 4.10 & 58.00 & $0.00^{* *}$ & $0.70^{* *}$ \\
\hline BW1 (points) & 2.50 & 0.78 & 2.50 & 0.63 & 0.00 & 0.00 & 58.00 & 1.00 & 0.00 \\
\hline BW2 (points) & 2.30 & 0.99 & 2.17 & 0.87 & 0.13 & 0.55 & 58.00 & 0.58 & 0.02 \\
\hline
\end{tabular}

EG - experimental group, CG - control group, Mean - mean value results, SD - standard deviation of the mean, Mean Diff EG-CG - differences obtained when the arithmetic mean of the control group is subtracted from the arithmetic mean of the experimental group, $\mathrm{t}$ - calculated $\mathrm{t}$-test value, $\mathrm{df}$ - degrees of freedom, $\mathrm{r}$ - $\mathrm{t}$-test statistical significance, Cohen'sd - calculated Cohen's d effect size used to indicate the standardized difference between two means, SLJstanding long jump; SABP - single-arm ball pushing; SUP - sit-ups; R25 - 25-meter run; SFB - seated forward bend; BW1 - wide bench walking; BW2 - narrow bench walking; statistical significance of differences ${ }^{*}<0,05,{ }^{* *}<0,01$. 
Based on the results presented in Table 3, which describes the differences between EG and CG at the final measurement, within the variables describing physical fitness, it can be seen that there was a difference between the EG and CG examinees. This difference can be seen in the SABP variable in favor of EG showing t-test statistical significance of $r=0.00$ and $0.56^{* *}$ - Cohen's d effect size. Also, the differences were noticed in the SUP variable in favor of EG where t-test statistical significance was $r=0.00$ and Cohen's d effect size was $0.57^{* *}, \mathrm{R} 25$ in favor of CG where t-test statistical significance was $r=0.00$ and the Cohen's d effect size was 0.16, as well as in the SFB variable in favor of EG, where t-test statistical significance was $r=0.00$ and the Cohen's d effect size $0.70^{* *}$. Upon finishing the final physical fitness measurement, other variables between the EG and CG subjects did not show any statistically significant differences.

Table 4 presents the multivariate analysis of covariance results of the applied variables for physical fitness estimation at the final measurement (the neutralization of recorded differences between the EG and CG at the initial measurement was done). It can be concluded that there is a statistically significant difference at the multivariate level between the EG and CG examinees at a significance level of $0.01(\mathrm{r}=0.000)$. The recorded difference occurs under the influence of the applied SSGP, and it can be concluded that it affects the transformation of physical fitness in the EG examinees.

Table 5 results show univariant differences in variables assessing physical fitness between EG and CG examinees at the final measurement with neutralization and partialization of the initial measurement results. It can be concluded that there is a statistically significant difference in the SLJ $(p=0.000), \operatorname{SABP}(p=0.001), \operatorname{SUP}(p$ $=0.000)$ variables at $p=0.01$ significance level. The established statistical significance for the R25 $(p=0.014)$ and $\mathrm{SFB}(\mathrm{p}=0.028)$ variables was at $\mathrm{pr}=0.05$ significance level. There were no statistically significant differences in the BW1 and BW2 variables.

Table 4. Multivariate analysis of covariance of physical fitness between EG and CG at the final measurement

\begin{tabular}{c|c|c|c|c|c}
\hline \hline Wilks' Lambda & $\mathbf{F}$ & $\mathbf{d f 1}$ & $\mathbf{d f 2}$ & $\mathbf{p}$ & Partial Eta Squared \\
\hline $\mathbf{0 . 4 2 1}$ & 10.541 & 6 & 46 & $0.000^{* *}$ & 0.579 \\
\hline \hline
\end{tabular}

Wilk's Lambda - Wilks' lambda test, F- F-approximation, df - degrees of freedom, $\mathrm{p}$ - statistical significance of differences, ${ }^{*}<0,05,{ }^{* *}<0,01$, Partial Eta Squared - effect size.

Table 5. Univariate analysis of covariance of physical fitness in EG and CG at the final measurement

\begin{tabular}{l|c|c|c|c|c|c}
\hline \hline \multicolumn{1}{c|}{ Variable } & $\begin{array}{c}\text { Adj. Mean } \\
\text { EG }\end{array}$ & $\begin{array}{c}\text { Adj. Mean } \\
\text { CG }\end{array}$ & $\begin{array}{c}\text { Adj. Mean } \\
\text { diff.(EG-CG) }\end{array}$ & F & r & $\begin{array}{c}\text { PartialEta } \\
\text { Squared }\end{array}$ \\
\hline SLJ (cm) & 83.42 & 76.82 & 6.60 & 21.68 & $0.000^{* *}$ & $0.30^{* * *}$ \\
\hline SABP (cm) & 5.36 & 4.98 & 0.38 & 11.85 & $0.001^{* *}$ & $0.19^{* * *}$ \\
\hline SUP (attempts) & 16.32 & 11.48 & 4.84 & 52.30 & $0.000^{* *}$ & $0.51^{* * *}$ \\
\hline R25 (s) & 5.61 & 5.72 & -0.11 & 6.54 & $0.014^{*}$ & $0.11^{* *}$ \\
\hline SFB (cm) & 26.79 & 22.34 & 4.45 & 5.12 & $0.028^{*}$ & $0.09^{* *}$ \\
\hline BW1 (points) & 2.50 & 2.50 & 0.00 &. &. &. \\
\hline BW2 (points) & 2.28 & 2.19 & 0.09 & 0.79 & 0.380 & $0.02^{*}$ \\
\hline \hline
\end{tabular}

EG - experimental group, CG - control group, Adj. Mean - adjusted arithmetic mean; Adj. Mean diff. - adjusted arithmetic mean differences; F - F test, $\mathrm{r}$ - significance level, statistical significance of differences $* *<0,01 * 0,05$; Partial Eta Squared - effect size (small ${ }^{*}$, medium ${ }^{* *}$, large ${ }^{* * *}$ ); SLJ-standing long jump; SABP - single-arm ball pushing; SUP - sit-ups; R25 - 25-meter run; SFB - seated forward bend; BW1 - wide bench walking; BW2 - narrow bench walking. 


\section{DISCUSSION}

This study examined the effect of a 12-week SSGP on physical fitness of adolescents diagnosed with ID. SSGP was compared with the program designed by the Ministry of Education, Science and Technological Development of the Republic of Serbia for adolescents with ID - MP.

Slight physical fitness results of both groups of respondents at the initial and final testing show that the ID has an impact on performance reduction in relation to persons without disabilities (18). The cause of this phenomenon should also be sought in previously documented studies that show that adolescents with IDs are less active than their peers without disabilities (13) (Table 2).

The results indicate that a 12-week SSGP implementation contributed to the improvement of EG physical fitness, while 12-week SSGP implementation contributed to the improvement of CG physical fit-ness to a lesser extent. The comparative analyzes of EG examinees after conducting SSGP showed that EG examinees' physical fitness is better and stronger compared to CG examinees (after conducting MP).

The results of $\mathrm{t}$-test at the initial measurement between EG and CG showed a statistically significant difference in favor of EG in the SABP and SFB variables, and a statistically significant difference in favor of $C G$ in the R25 variable. Such a statistically significant difference between the groups at this age can be the result of intensive growth and body development, but different lifestyles and places of residence, as well as being socially accepted in non-school environments, may affect the results (19-21). The examinees were not familiar with the conducted tests, which might have resulted in statistically significant differences at the initial measurement. Similar data was obtained at the initial measurement of physical fitness in adolescents with ID who were not active athletes or did not have any organized physical and extracurricular activities $(19,22,23)$.

The descriptive statistics results at the final measurement of the variables describing physical fitness of EG examinees showed an improvement. The mean values of the physical fitness variables show a significant growth in almost all variables: SLJ, SABP, SUP, SFB, $\mathrm{BW} 2$. The variables in which there was no increase in the mean values of the results are: R25 and BW1. These results show that the implementation of SSGP has led to positive changes. These changes are visible in strength (SFB, SLJ, SABP), flexibility (SFB) and balance (BW2). A more noticeable difference in the mean values is achiev- ed within the repetitive force variable (SFB), which coincides with earlier studies $(23,24)$. A variable in which there was no increase in the mean values of the results at the final measurement is speed. Speed represents a physical fitness to a great extent affected by innate disposition and can only be insignificantly improved. As the results of the earlier studies show, the improvement requires a long period of time $(23,24)$.

The descriptive statistics results of CG which was on MP show a slight decrease in the mean values of the results: SLJ, SABP, SUP, SFB, BW2. The variable in which there was no increase in the mean values of the results is R25, while BW1 remained unchanged. Based on the results, a slight decrease in the mean values of the results concerning measured variables that assess physical fitness can be seen.

Statistical analyses determined the difference at the initial measurement concerning basic physical fitness parameters between EG and CG. The results indicated that the groups were unbalanced concerning the following variables: SABP in favor of EG, where t-test statistical significance was $p=0.00$ and the Cohen's d effect size was $0.49 *$, SFB in favor of EG examinees with t-test statistical significance of $\mathrm{p}=0.04$ and the Cohen's $\mathrm{d}$ effect size of $0.35^{*}$, whereas the difference in the R25 variable was in favor of CG with t-test statistical significance being $\mathrm{p}=0.00$ and 0.14 Cohen's d effect size. The uneven results of the groups at the initial measurement are the reason why the examinees were randomly selected so that they could possess identical physical and mental abilities. Such a procedure is not precedent, since a similar method has been used in some earlier studies $(23,25)$. The explanation for these results lies in the physiological development which is intensive in adolescence, where the improvement of basic physical fitness comes naturally without implementing any physical activities (26), and the distinctions at the initial measurement result from social elements and financial conditions (27, 28).

The final presentation of the research findings, after the implementation of SSGP, with regard to physical fitness, included analyzing the quantitative differences between EG and CG using a t-test. The results of quantitative differences indicated that there were statistically significant improvements in favor of EG in SABP, SUP, R25 and SFB variables. The value of a statistically significant difference was $p=0.00$, while the effect size indicator in the mentioned variables ranged from medium to high values. The value of statistical improvement in the strength range, and above all repetitive strength, was extremely high whereas it was extremely low in the field of 
speed. Other variables reflected medium effect sizes. The values thus obtained confirm the physiological explanation, that is, physical fitness with the least degree of innate developmental limitations have been increased to the highest statistical significance, while speed as a physical fitness, which is more than $90 \%$ inborn, has increased to a small extent. The obtained results of the final measurement are identical to the results from previous studies that were concerned with the development of physical fitness in adolescents with ID after experimental physical activities $(23,25,29)$. The area in which there were no statistically significant changes was within the explosive power of the lower limbs (standing long jump) and balance. These results are similar to the results from some earlier studies $(23,30)$ showing that balance is highly correlated with intelligence dubbed as motor intelligence.

The results of ANCOVA and MANCOVA analyses dealing with physical fitness in the examinees confirmed the quantitative and qualitative results obtained from descriptive parameters as well as the t-test. These analyses determined the statistically significant effect of the EG of adolescent examinees diagnosed with ID in the area of physical fitness. The differences statistically proven for each variable individually are: $\operatorname{SLJ}(\mathrm{p}=0.000)$, SABP $(p=0.001)$, SUP $(p=0.000)$, at the level of significance $p=0.01$. The statistical significance was determined at the level of significance $p=0.05$ for the MT25 ( $p=$ $0.014)$ and SFB $(p=0.028)$ variables. There were no statistically significant differences in the BW1 and BW2 variables. The results obtained in this way are consistent with previous studies that dealt with the effects of exer- cise in order to improve physical fitness in adolescents with $\operatorname{ID}(23,30,3132)$. According to the data, it can be pointed out that 12-week SSGP (basketball and football) with 30-minute trainings 4 times a week affects the improvement of physical fitness, and above all the skills of strength, flexibility and speed. SSGP as a PE program for adoles-cents with ID with the contents of sports games might be considered for implementation in the system of special schools.

\section{CONCLUSION}

The results of this research have shown significant changes in physical fitness parameters in adolescents diagnosed with ID, which resulted from a 12-week sports games program. SSGP affected the changes in physical fitness among EG, but statistically insignificant changes were noted among CG examinees. More specifically, statistically significant changes related to the changes in physical fitness refer to the parameters of strength, speed and flexibility. There were no statistically significant changes concerning coordination in both EC and CG. In general, the results of this study indicate the following: SSGP conducted within twelve-week classes of specially dosed sports activities such as football and basketball significantly contributed to the development of physical fitness in adolescents with ID. In order to achieve the most suitable physical exercise program, it is required to conduct further research in adolescents with ID. 


\section{References}

1. McKenzie K, Milton M, Smith G et al. Systematic review of the prevalence and incidence of intellectual disabilities: current trends and issues. Curr Dev Disord Rep 2016; 3: 104-15. https://doi.org/10.1007/s40474-016-0085-7

2. Sheehan R, Hassiotis A, Walters K et al. Mental illness, challenging behavior, and psychotropic drug prescribing in people with intellectual disability: UK population based cohort study. Bmj 2015; 351, h4326. https://doi.org/10.1136/bmj.h4326

3. Schalock RL, Borthwick-Duffy SA, Bradley VJ et al. Intellectual disability: Definition, classification, and systems of supports. American Association on Intellectual and Developmental Disabilities, Washington (DC), 2010: 1-259.

4. Luckasson R, Borthwick-Duffy S, Buntinx WH et al. Mental retardation: Definition, classification, and systems of supports, $10^{\text {th }}$ ed. Washington, DC: American Association on Mental Retardation.

5. Bojanin S, Kolar D, Kolar M. Mental retardation and psychotic disorders. Psihijatrija danas 2002; 34(32743.

6. Jeng SC, Chang CW, Liu WY et al. Exercise training on skill-related physical fitness in adolescents with intellectual disability: A systematic review and metaanalysis. Disabil Health J 2017; 10: 198-206. https://doi.org/10.1016/j.dhjo.2016.12.003

7. Chan KL, Lo CK, Ip P. Associating disabilities, school environments, and child victimization. Child Abuse Neg 2018; 83: 21-30.

https://doi.org/10.1016/j.chiabu.2018.07.001

8. Bossink LW, van der Putten AA, Vlaskamp C. Understanding low levels of physical activity in people with intellectual disabilities: A systematic review to identify barriers and facilitators. Res Dev Disabil 2017; 68: 95-110.

https://doi.org/10.1016/j.ridd.2017.06.008

9. King M, Shields N, Imms C et al. Participation of children with intellectual disability compared with typically developing children. Res Dev Disabil 2013; 34(5): 1854-62.

https://doi.org/10.1016/j.ridd.2013.02.029

10. Chien, CW, Rodger S, Copley J. Differences in patterns of physical participation in recreational activeties between children with and without intellectual and developmental disability. Res Dev Disabil 2017; 67: 9-18.

https://doi.org/10.1016/j.ridd.2017.05.007

11. Einarsson IÓ, Ólafsson Á, HinriksdÓttir, G et al. Differences in physical activity among youth with and without intellectual disability. Med Sci Sports Exerc 2015; 47(2): 411-18.

https://doi.org/10.1249/MSS.0000000000000412

12. Golubović Š, Maksimović J, Golubović B et al. Effects of exercise on physical fitness in children with intellectual disability. Res Dev Disabil 2012; 33(2): 608-14.

https://doi.org/10.1016/j.ridd.2011.11.003

13. Frey GC, Temple VA et Stanish HI. Interventions to promote physical activity for youth with intellectual disabilities. Salud Publica Mex 2017; 59: 437-45.

https://doi.org/10.21149/8203

14. Lantz E Marcellini A. Sports games for people with intellectual disabilities. Institutional analysis of an unusual international configuration. Sport in Society 2018; 21(4): 635-48 https://doi.org/10.1080/17430437.2016.1273612

15. Özer D, Baran F, Aktop A et al. Effects of a Special Olympics Unified Sports soccer program on psychosocial attributes of youth with and without intellecttual disability. Res Dev Disabil 2012; 33: 229-39. https://doi.org/10.1016/j.ridd.2011.09.011

16. Council of Europe (1993). Eurofit: Handbook for the Eurofit Tests of Physical Fitness. Strasbourg: Council of Europe.

17. Eston R, Hawes M, Martin A et al. Human body composition. In: Eston R Reilly T. (ed), Kinanthropometry and exercise physiology laboratory manual: 
tests, procedures and data. Volume One: Anthropometry.Routledge, London, 2009: 3-53.

https://doi.org/10.4324/9780203868744

18. Stanišić Z, Kocić M, Aleksandrović M, et al. The effects of an adapted basketball training program on the physical fitness of adolescents with mental retardation: a pilot study. Serb J Exp Clin Res 2012; 13: 103-7.

https://doi.org/10.5937/sjecr13-2328

19. Alruwaih ME. Effects of soccer unified program on adaptive behavioral for children with mental retardation. "Ovidius" Univ. Ann. Ser. Phys. Educ. Sport. Sci., Mov. Health (Online) 2015; 15: 436-42.

20. Sunko E. Društveno povijesni kontekst odgoja i obrazovanja djece s teškoćama u razvoju. Skol Vjesn 2016; 65: 601-20.

21. Kocić M, Bojić I, Aleksandrović M et al. Physical Activity in Adolescent with Mental Retardation: Is Adapted Basketball Training Adequate Stimulus to Improve Cardiorespiratory Fitness and Sport SkillsPerformance? Acta Fac Med Naiss 2017; 34: 159-68. https://doi.org/10.1515/afmnai-2017-0018

22. Salaun L, Berthouze-Aranda SE. Physical fitness and fatness in adolescents with intellectual disabilities. J Appl Res Intellect Disabil 2012; 25: 231-9. https://doi.org/10.1111/j.1468-3148.2012.00659.x

23. Top E. The effect of swimming exercise on motor development level in adolescents with intellectual disabilities. Am J Spo Sci Med 2015; 3: 85-9.

24. Collins K \& Staples K. The role of physical activity in improving physical fitness in children with intellectual and developmental disabilities. Res Dev Disabil 2017; 69: 49-60. https://doi.org/10.1016/j.ridd.2017.07.020

25. Giagazoglou P, Arabatzi F, Dipla K et al. Effect of a hippotherapy intervention program on static balance and strength in adolescents with intellectual disabilities. Res Dev Disabil 2012; 33: 2265-70.

https://doi.org/10.1016/j.ridd.2012.07.004
26. Barnett LM, Van Beurden E, Morgan PJ et al. Childhood motor skill proficiency as a predictor of adolescent physical activity. J Adolesc Health 2009; 44: 2529.

https://doi.org/10.1016/j.jadohealth.2008.07.004

27. Wall AT. The developmental skill-learning gap hypothesis: Implications for children with movement difficulties. Adapt Phys Activ Q 2004; 21: 197-218.

https://doi.org/10.1123/apaq.21.3.197

28. Hartman E, Houwen S, Scherder E et al. On the relationship between motor performance and executive functioning in children with intellectual disabilities. J Intellect Disabil Res 2010; 54 : 468-77. https://doi.org/10.1111/j.1365-2788.2010.01284.x

29. Carmeli E, Zinger-Vaknin T, Morad M et al. Can physical training have an effect on wellbeing in adults with mild intellectual disability? Mech Ageing Dev 2005; 126: 299-304.

https://doi.org/10.1016/j.mad.2004.08.021

30. Blomqvist S, Olsson J, Wallin L et al. Adolescents with intellectual disability have reduced postural balance and muscle performance in trunk and lower limbs compared to peers without intellectual disability. Res Dev Disabil 2013; 34: 198-206.

https://doi.org/10.1016/j.ridd.2012.07.008

31. Wouters, M., Evenhuis, H. M., \& Hilgenkamp, T. I. Physical activity levels of children and adolescents with moderate-to-severe intellectual disability. J Appl Res Intellect Disabil 2018; DOI: 10.1111/ jar.12515

https://doi.org/10.1111/jar.12515

32. Crnic, KA, Neece, CL., McIntyre,L. Letal). Intellectual disability and developmental risk: Promoting intervention to improve child and family well-being. Child Dev 2017; 88: 436-45. https://doi.org/10.1111/cdev.12740 


\title{
Efekti specijalnog programa sportskih igara na fizičke sposobnosti adolescenata sa intelektualnim invaliditetom
}

\author{
Aleksandar Pejčić, Miodrag Kocić, Dragana Berić, Goran Kozomara, Marko Aleksandrović \\ Univerzitet u Nišu, Fakultet sporta i fizičkog vaspitanja, Niš, Srbija
}

\section{SAŽETAK}

Cilj istraživanja bio je da se utvrde efekti specijalnog programa sportskih igara na poboljšanje fizičkih sposobnosti adolescenata sa intelektualnim invaliditetom (ID).

Za potrebe dvostruke prospektivne studije regrutovano je 122 adolescenta uzrasta od 13 do 17 godina sa lakim ID podeljenih u dve grupe, eksperimentalnu (EG) i kontrolnu (KG). EG bila je podvrgnuta specijalnom programu sportskih igara (SSGP) koji je trajao 12 sedmica, sa učestalošću od četiri puta sedmično i dužinom trajanja sesije od $30 \mathrm{~min}$. KG bila je podvrgnuta regularnom programu Ministarstva prosvete, nauke i tehnološkog razvoja Republike Srbije (MP) koji je istog trajanja, sedmične učestalosti i dužine trajanja sesije, s tim da je jedna sesija sedmično bila čas izabranog sporta. Podaci za po 30 adolescenata u okviru EG i KG uzeti su za dalju analizu.

Fizički fitnes ispitanika je testiran pomoću testova iz Eurofit baterije testova: skok udalj iz mesta (SUM), bacanje medicinke (BMED), trbušnjaci (TRB), trčanje na 25 metara (T25), pretklon sa dosezanjem u sedu (PSED), hodanje na širokoj klupi (HODK1) i hodanje na uskoj klupi (HODK2).

SSGP imao je efekte na statistički značajna poboljšanja kod EG u eksplozivnoj snazi ruku, lokalnoj izdržljivosti mišića, brzini i fleksibilnosti kuka.

Rezultati ANOVA i MANOVA ukazali su da posle primene SSGP postoji statistički značajna pozitivna razlika u korist EG u odnosu na KG.

Može se zaključiti da je SSGP doprineo razvoju fizičke spremnosti u značajnijoj meri nego MP kod adolescenata sa ID.

Ključne reči: intelektualni invaliditet, fizičke sposobnosti, adolescenti 